JURNAL HUMANIORA

TEKNOLOGI

Vol. II No.I; Oktober 2016

\title{
IMPLEMENTASI KEBIJAKAN BAHASA DAN IMPLIKASINYA DALAM PENGUATAN IDENTITAS, INTEGRITAS, DAN PLURALITAS BANGSA
}

\author{
AHMAD AMIN DALIMUNTE \\ UIN Sumatera Utara
}

\begin{abstract}
Abstrak
Jauh sebelum terbentuk Negara Indonesia, Bahasa sebagai sebuah entitas dalam tatanan kebangsaan selalu mendapat perhatian serius oleh para pejuang kemerdekaan maupun kaum cendikiawan. Urgensi kebahasaan khususnya pada bahasa nasional ternyata sangat disadari hingga kini oleh pemerintah. Meskipun demikian, setelah 64 tahun Indonesia merdeka, baru pada tahun 2009 diterbitkan undang-undang No. 24/2009 yang mengatur tentang Bahasa Nasional, Bahasa Indonesia. Tidak hanya itu, sejak 2002, bahasa daerah sudah dimasukkan kedalam amandemen ke-4 UUD 1945 (pasal 32). Hal ini patut diapresiasi. Tetapi sayangnya, tujuh tahun sudah berjalan, implementasi kebijakan bahasa ini dinilai belum optimal. Ditambah lagi tantangan zaman yang semakin rumit menyebabkan persoalan kebahasaan tersebut semakin kompleks yang membutuhkan perhatian banyak pihak. Isu-isu kebahasaan hari ini bukanlah semata-mata milik bahasa nasional. Ancaman kepunahan bahasa-bahasa daerah di negeri seribu bahasa ini sepertinya hampir luput dari perhatian pemerintah kita. Padahal, kepunahan bahasa akan menggiring ke arah kepunahan budaya yang pada akhirnya dapat menghilangkan jati diri bangsa yang tentunya bertentangan dengan Visi Indonesia 2020 tentang kemandirian bangsa. Oleh sebab itu, isuisu kebahasaan baik nasional terlebih-lebih regional haruslah menjadi perhatian khusus pemerintah karena hal ini bersinggungan erat dengan 3 aspek krusial yang menentukan masa depan Indonesia sebagai sebuah Negara bangsa, yakni: identitas, integritas, dan pluralitas bangsa Indonesia.
\end{abstract}

Kata kunci: implementasi, kebijakan, bahasa, identitas, integritas, pluralitas.

\section{PENDAHULUAN}

\section{Latar Belakang}

Bahasa sebagai sebuah entitas penting dalam tatanan kebangsaan sesungguhnya telah lama menjadi perhatian serius sejak masa pra kemerdekaan hingga terbentuknya indonesia menjadi negara yang diakui kemerdekaannya oleh dunia internasional. Eksistensi bahasa indonesia memiliki peran signifikan dalam menyatukan seluruh rakyat indonesia untuk merebut kemerdekaan dari tangan penjajah. Keberhasilan bahasa melayu yang merupakan cikal bakal bahasa indonesia dan kemudian menjadi bahasa nasional bagi bangsa yang memiliki ribuan pulau yang terbentang dari aceh sampai 
papua dan ratusan keragaman suku, bahasa, dan budaya memang dikagumi oleh para pakar linguistik dunia. Keberhasilan perencanaan bahasa nasional, bahasa indonesia, disebut-disebut sebagai kesuksesan politik/perencanaan bahasa paling fenomenal.

Urgensi kebahasaan khususnya pada bahasa nasional ternyata memang sangat disadari oleh pemerintah. Hal ini terlihat dari beberapa usaha dan kebijakan yang dilakukan pemerintah meliputi penerbitan Undang-Undang No. 24/2009 yang mengatur tentang Bahasa Nasional, Bahasa Indonesia. Tidak hanya itu, sejak 2002, bahasa daerah sudah dimasukkan kedalam amandemen ke-4 UUD 1945 (pasal 32). Hal ini patut diapresiasi. Tujuh tahun regulasi ini sudah berjalan namun implementasi kebijakan bahasa ini dinilai belum optimal. Ditambah lagi tantangan zaman yang semakin rumit menyebabkan persoalan kebahasaan tersebut semakin kompleks yang membutuhkan perhatian banyak pihak. Ditambah lagi, isu-isu kebahasaan hari ini bukanlah sematamata milik bahasa nasional. Ancaman kepunahan bahasa-bahasa daerah di negeri seribu bahasa ini sepertinya hampir luput dari perhatian pemerintah kita. Padahal, kepunahan bahasa akan menggiring ke arah kepunahan budaya yang pada akhirnya dapat menghilangkan jati diri bangsa yang tentunya bertentangan dengan Visi Indonesia di masa depan khususnya tentang kemandirian bangsa.

Karena beberapa alasan tersebut, penulis melihat pentingnya untuk melakukan sebuah kajian tentang penerapan kebijakan Bahasa dan bagaimana hal tersebut dapat mempengaruhi ketahanan dan orisinilitas bangsa Indonesia di masa depan.

\section{Rumusan Masalah}

Dalam kajian ini, ada dua rumusan masalah yang menjadi fokus utama pembahasan.

1. Apa yang mendorong perlunya implementasi kebijakan bahasa di Indonesia?

2. Apa implikasi dari implementasi kebijakan bahasa tersebut dalam penguatan identitas, integritas dan pluralitas bangsa Indonesia?

\section{Metodologi Penelitian}

Dalam kajian ini metode kualititatif jenis deksriptif digunakan dengan cara pendeskripsian dokumen-dokumen regulasi kebahasaan yang ada lalu menarik sebuah narasi besar dari hasil analisis tersebut terhadap implikasi yang bersifat sosial, politik, kebahasaan dan kebangsaan. 


\section{Perencanaan bahasa}

Kaplan dan Baldauf (1997:3) menjelaskan perencanaan bahasa atau Language Planning sebagai kesatuan ide, hukum, peraturan dan implementasi untuk mencapai perubahan yang telah direncanakan dari pemakaian suatu bahasa pada suatu masyarakat atau negara.

Perencanaan bahasa dinilai sangat penting karena perencanaan bahasa dapat menjadi alat untuk mencapai beberapa tujuan antara lain : untuk mencapai kesatuan dan harmoni nasional, memperkuat integrasi komunikasi masyarakat secara lokal maupun internasional dengan bangsa-bangsa lain di dunia, merevitalisasi sebuah bahasa, memajukan dan menstandarisasi sebuah bahasa, mengembalikan pergeseran bahasa (language shift), bahkan lebih jauh lagi mencegah kematian sebuah bahasa atau menghidupkan kembali bahasa-bahasa yang telah mati.

Pakar perencanaan bahasa, Haugen dalam Kaplan dan Baldauf (1997 :29-37), telah merancang skema prencanaan bahasa yang tepat sebagai berikut:

Tabel 1. Skema Perencanaan Bahasa

\begin{tabular}{|l|l|l|}
\hline \multicolumn{1}{|c|}{$\begin{array}{c}\text { Perencanaan } \\
\text { Bahasa }\end{array}$} & $\begin{array}{l}\text { Bentuk (Perencanaan } \\
\text { Kebijakan) }\end{array}$ & Fungsi \\
\hline $\begin{array}{l}\text { Masyarakat } \\
\text { (Perencanaan } \\
\text { status) }\end{array}$ & $\begin{array}{l}\text { 1. Pemilihan norma } \\
\text { a. Identifikasi Masalah } \\
\text { b. Alokasi norma-norma }\end{array}$ & $\begin{array}{l}\text { 3. Implementasi (melalui } \\
\text { pendidikan) } \\
\text { a. Perbaikan } \\
\text { b. Evaluasi }\end{array}$ \\
\hline $\begin{array}{l}\text { Bahasa } \\
\text { Korencanaan }\end{array}$ & $\begin{array}{l}\text { 2. Kodifikasi (Prosedur } \\
\text { standarisasi) }\end{array}$ & $\begin{array}{l}\text { 4. Elaborasi } \\
\text { (Pengembangan }\end{array}$ \\
& $\begin{array}{l}\text { a. Sistem Ejaan } \\
\text { bembakuan Tata }\end{array}$ & $\begin{array}{l}\text { Fungsional) } \\
\text { a. Modernisasi Istilah } \\
\text { b. Pengembangan Gaya } \\
\text { c. Leksikalisasi }\end{array}$ \\
\hline
\end{tabular}

Pada makalah ini, penulis hanya berfokus pada kategori pertama perencanaan bahasa, yaitu perencanaan status atau lebih populer dengan istilah status planning.

\section{Perencanaan Status}

Perencanaan Status diartikan sebagai aspek perencanaan bahasa yang terutama mencerminkan isu-isu sosial dan keprihatinan dan berada di luar bahasa yang sedang 
direncanakan. Perencanaan status juga disamakan dengan kebijakan bahasa atau politik bahasa. Perencanaan status melibatkan alokasi bahasa untuk domain sosial yang berbeda, seperti lingkup resmi, pendidikan, bisnis, media, dll. Dua isu yang membentuk perencanaan status adalah pemilihan bahasa dan implementasi bahasa.

\section{Pemilihan Bahasa}

Pemilihan bahasa berfokus pada pengembangan kebijakan bahasa. Seleksi melibatkan pilihan bahasa untuk masyarakat melalui Pemerintah. Keputusan tersebut biasanya dilakukan di antara bahasa dan dialek yang bersaing. Bahasa atau aspek bahasa yang dipilih ditetapkan menjadi bentuk linguistik tertentu yang menjadi norma dan memiliki status dalam masyarakat.

\section{Implementasi Bahasa}

Sebuah pelaksanaan perencanaan bahasa berfokus pada pengadopsian dan penyebaran bentuk bahasa yang telah dipilih dan dikodifikasi. Hal ini sering dilakukan melalui sistem pendidikan dan hukum atau peraturan yang mendorong atau mengharuskan penggunaan standar. Bamgbose (1991:110) menunjukkan bahwa implementasi sangat terkait dengan kebijakan karena pelaksanaan tanpa adanya keputusan kebijakan sulit untuk dicapai, sedangkan pembuatan kebijakan tanpa implementasi tidak akan mengalami banyak kemajuan. Dalam prakteknya, keputusan kebijakan yang ditujukan untuk pemberian status bahasa dalam domain masyarakat tertentu yang pertama yang diambil, dan kemudian diimplementasikan dalam beberapa cara.

\section{Masalah-masalah kebahasaan}

Masalah-masalah yang muncul yang mendorong perlunya regulasi bahasa tidak hanya terbatas pada masalah-masalah non-kebahasaan seperti pengaruh globalisasi maupun ancaman disintegrasi bangsa tetapi juga banyak masalah kebahasaan yang harus disikapi. Permasalahan kebahasaan tersebut terjadi pada 2 ranah pemakaian bahasa yakni permasalahan pemakaian Bahasa Indonesia dan permasalahan pada bahasa-bahasa daerah.

\section{Masalah penggunaan bahasa indonesia}

Jumlah penutur bahasa Indonesia mengalami peningkatan tajam dari dekade ke dekade. Dari 214 juta penduduk yang disurvey oleh BPS (2010), $92 \%$ penduduk Indonesia mampu berbahasa Indonesia. Tingginya jumlah penutur bahasa Indonesia 
tidak berarti pemakaian bahasa Indonesia sebagai bahasa resmi tidak ada masalah. Masalah tersebut antara lain:

a. Sikap berbahasa yang negatif

Sikap Bahasa adalah posisi linguistik, persepsi, dan tindakan masyarakat penutur terhadap bahasa mereka kuasai (Jendra, 2010). Gagasan tentang sikap bahasa adalah pemahaman penting dalam konsep masyarakat tutur. Sikap bahasa dapat bersifat positif maupun negatif. Sikap bahasa yang positif akan diikuti dengan tindakan positif, sebaliknya sikap bahasa yang negatif juga ditunjukkan oleh tindakan yang negatif.

Pada masa orde baru sejak kemampanan Indonesia dalam bidang ekonomi banyak muncul kelompok masyarakat ekonomi menengah ke atas. Kelompok masyarakat elit ini yang kebanyakan golongan dengan ekonomi mapan dan dapat mengecap pendidikan tinggi berasumsi bahwa kemampuan berbahasa inggris bersifat sangat prestise yang menandakan status sosial seseorang dalam pergaulan sehingga acap kali mereka sengaja atau tidak sengaja menggunakan atau menyelipkan kata-kata berbahasa inggris dalam percakapan (Sneddon, 2003). Fenomena sosiolinguistik ini diistilahkan dengan kontak bahasa. Jendra (2010:67) mendefinisikan fenomena ini sebagai situasi sosiolinguistik di mana dua atau lebih bahasa yang digunakan secara bersamaan atau dicampur satu dengan yang lain. Fenomena ini masih bertahan hingga kini bahkan lebih meluas lagi ke aspek-aspek kehidupan sejak arus globalisasi melanda dunia.

b. Pemakaian bahasa Indonesia yang dipengaruhi oleh bahasa Inggris

Penyebaran globalisasi di dunia telah mempengaruhi perkembangan zaman dan berbagai aspek kehidupan, seperti pendidikan, ilmu pengetahuan, teknologi, politik, hukum, ekonomi, sosial dan budaya. Dalam bidang pendidikan dan IPTEK, bahasa Inggris membantu kemampanan bahasa Indonesia untuk mengekspresikan berbagai konsep dan ide dalam pendidikan dan ilmu pengetahuan melalui pengayaan istilahistilah sains. Dalam bidang ekonomi dan bisnis, banyak terjadi penggunaan bahasa Indonesia yang melanggar kaidah dan undang-undang kebahasaan. Penulis mengamati sangat banyak iklan baik di media cetak maupun elektronik yang secara serampangan menggunakan bahasa Inggris secara parsial maupun utuh. Berbagai merek barang, jasa, nama toko, gedung, apartemen, komplek perdagangan dan perkantoran, organisasi maupun lembaga pendidikan juga tidak mau ketinggalan 
zaman untuk menggunakan bahasa inggris. Padahal, hal ini sudah diatur dalam undang-undang no 24/2009 (pasal 36).

\section{Level regional : kondisi bahasa-bahasa daerah}

Indonesia merupakan negara yang memiliki khasanah bahasa daerah yang tertinggi di benua Asia setelah Papua Nugini. Banyak perbedaan diantara para pakar linguistik dalam menghitung jumlah bahasa daerah di Indonesia yang disebabkan perbedaan kriteria dalam mengklasifikasikan bahasa dan dialek. Tetapi banyak juga yang menyebutkan jumlah bahasa di Indonesia pada kisaran 500-700 bahasa yang berarti bahwa $10 \%$ dari bahasa-bahasa di dunia berada di Indonesia. Diantara jumlah tersebut, terdapat 14 bahasa mayoritas dengan penutur masing-masing berjumlah diatas 1 juta orang (Sneddon, 2003). 5 bahasa diantaranya adalah bahasa Jawa sebagai bahasa dengan penutur terbanyak (75 juta penutur), Bahasa Sunda (27 juta), Madura (9 juta), Minang (6,5 juta) dan Bugis (3,6 juta), selebihnya tentu adalah bahasa-bahasa minoritas yang sedikit penggunanya. Kelompok bahasa minoritas inilah yang sangat dicemaskan oleh PBB melalui UNESCO akan hilang disebabkan terputusnya rantai transmisi bahasa.

a. Gejala kematian bahasa ibu

Kepunahan bahasa merupakan bencana besar bagi kemanusiaan. Ini merupakan kehilangan yang sangat berharga dalam sejarah peradaban manusia. Harrison (2007: 15-18) mencatat 3 kerugian besar atas hilangnya bahasa, yaitu: kehilangan sistem pengetahuan, kehilangan warisan budaya, dan tidak terungkapnya sistem kognitif manusia. Senada dengan Harrison, Direktur Jenderal UNESCO, Koichiro Matsuura, menekankan bahwa "Kematian bahasa menyebabkan hilangnya berbagai bentuk warisan budaya tak benda, khususnya warisan berharga dari tradisi dan ekspresi lisan masyarakat penuturnya, mulai dari puisi, legenda hingga pribahasa dan anekdot. Hilangnya bahasa juga merugikan pemahaman manusia terhadap keanekaragaman hayati, karena bahasa mentransfer banyak perbendaharaan pengetahuan tentang alam semesta. (UNESCO :2011)

Menurut dokumen UNESCO, 2.500 (43\%) dari 6.000 bahasa dunia yang dipakai saat ini terancam punah, 178 bahasa dengan penutur berkisar 10-50 orang, 199 bahasa dituturkan oleh kurang dari 10 orang, dan sekitar 200 bahasa telah mati.

Sebuah rasio yang sangat berbanding terbalik antara jumlah bahasa yang ada dengan jumlah penuturnya. Kira-kira 97 persen dari populasi dunia saat ini memakai bahasa yang jumlahnya hanya 4 persen dari bahasa-bahasa dunia, 
sementara hanya 3 persen penduduk dunia yang merupakan penutur dari 96 persen dari bahasa-bahasa tersebut. Diperkirakan dalam 100 tahun ke depan, sekitar 90 persen dari bahasa-bahasa tersebut akan hilang.

UNESCO (2011) menetapkan 6 tingkat keterancaman bahasa sebagai berikut.

Tabel 2 Tingkat Keterancaman Bahasa

\begin{tabular}{|l|l|}
\hline $\begin{array}{l}\text { Tingkat } \\
\text { Keterancaman }\end{array}$ & Transmisi Bahasa antar generasi \\
\hline Aman & $\begin{array}{l}\text { Bahasa dipakai oleh dan dari generasi ke } \\
\text { generasi (generasi tua, sekarang dan yang akan } \\
\text { datang) }\end{array}$ \\
\hline Rentan/Tidak Aman & $\begin{array}{l}\text { Sebagian besar anak-anak masih memakainya } \\
\text { tapi hanya di rumah. }\end{array}$ \\
\hline Terancam & $\begin{array}{l}\text { Anak-anak tidak lagi belajar bahasa ibu di } \\
\text { rumah }\end{array}$ \\
\hline Terancam parah & $\begin{array}{l}\text { Bahasa hanya dipakai oleh Generasi pertama. } \\
\text { Sementara generasi kedua (orang tua) hanya } \\
\text { dapat memahami tapi tidak dapat } \\
\text { menggunakannya dalam komunikasi. }\end{array}$ \\
\hline Terancam punah & $\begin{array}{l}\text { Generasi penutur termuda adalah kakek-nenek } \\
\text { tapi mereka jarang menggunakannya dan } \\
\text { secara parsial. }\end{array}$ \\
\hline Punah/hilang & $\begin{array}{l}\text { Tidak ada penutur yang tersisa, generasi } \\
\text { pemakainya telah mati. }\end{array}$ \\
\hline
\end{tabular}

Kondisi yang sama juga mengancam situasi keberagaman bahasa ibu di Indonesia. Ancaman kematian bahasa menghantui daerah-daerah yang memiliki kemajemukan bahasa yang tinggi seperti pulau Sulawesi dan Papua. Bahasa-bahasa di Papua antara lain bahasa Mapia, Miere , Bahasa Dusner, Sentani, Nafri, Kayu Polu, Skouw, Tobati-Enggros dikategorikan sebagai bahasa-bahasa yang terancam menghilang karena penuturnya yang sangat sedikit. Di pulau Sulawesi juga terdapat bahasa Moronene yang terancam punah bahkan bahasa Kayeli dan Hukumina yang ada di Maluku dikabarkan telah punah (UNESCO, 2011). Fenomena kepunahan bahasa di Indonesia ibarat fenomena gunung es yang terlihat pada permukaanya saja oleh sebab itu dibutuhkan perhatian khusus dari pemerintah kita untuk mendorong peningkatan kuantitas dan kualitas penelitian-penelitian pada bidang ini.

b. Fenomena pergeseran bahasa Lokal 
Banyak faktor yang menyebabkan sebuah bahasa hilang, salah satu diantaranya adalah pergeseran bahasa (language shift). Pergeseran bahasa merupakan suatu kondisi dimana sebuah bahasa ditinggalkan oleh para penggunanya dan mereka beralih menggunakan bahasa yang baru. Konsekuensi logis yang terjadi adalah jumlah penutur bahasa tersebut akan berkurang dan perlahan -lahan bahasa itu tidak memiliki penutur lagi. Dominasi bahasa mayoritas terhadap bahasa minoritas menyebabkan bahasa itu terpinggirkan dan kemudian akan terlupakan. Pada titik ini, bahasa itu berada dalam level kepunahan (extinct). Politik bahasa nasional atau bahasa resmi yang diterapkan oleh suatu negara sedikit atau banyak tentu mencederai bahasa-bahasa lokal yang terdapat di negara tersebut. Pada umumnya, ini terjadi pada negara-negara yang sedang mengalami transisi atau perubahan politik atau dalam tahap pembentukan dan penguatan semangat nasionalisme seperti yang terjadi di Rusia, Jepang, bahkan Indonesia.

\section{Regulasi kebahasaan dan Implikasinya dalam Penguatan Identitas, Integritas dan Pluralitas Bangsa}

Sejauh pengamatan penulis, ada 4 kebijakan pemerintah pusat yang berkaitan dengan bahasa nasional maupun bahasa daerah, yaitu:

\section{UUD 1945 (Pasal 32 dan 36)}

Pasal 36 UU 1945 telah menggariskan bahwa Bahasa Indonesia adalah Bahasa Negara. Pernyataan ini bukan sekedar pernyataan biasa tetapi memiliki konsekuensi yang menjadikan bahasa Indonesia berfungsi sebagai Identitas (jati diri) Bangsa Indonesia.

Identitas bangsa indonesia adalah ciri, penanda, jati diri yang melekat pada suatu dan berfungsi untuk membedakannya dengan bangsa-bangsa lain di dunia. Bentukbentuk identitas nasional meliputi bahasa nasional (bahasa indonesia), ideologi negara (pancasila), Semboyan nasional (Bhineka Tunggal Ika), Bendera negara (Sang Merah Putih).

Seperti halnya kata pepatah bahwa Bahasa menunjukkan Bangsa. Identifikasi bangsa atau negara yang menggunakan Bahasa Indonesia sebagai Bahasa Nasionalnya tentulah sangat mudah karena Indonesia merupakan satu-satunya negara di dunia yang menjadikan bahasa Indonesia sebagai bahasa nasionalnya. Ini bukan sekedar identitas tapi harga diri sekaligus kebanggaan karena kita tidak mau menjadikan bahasa bangsa-bangsa yang telah menjajah kita, bahasa Belanda, bahasa Portugis, 
bahasa Jepang, ataupun Bahasa Inggris, sebagai bahasa resmi kita seperti yang dilakukan oleh Malaysia, Singapura, Filipina dan India.

Selanjutnya, melalui amandemen ke-4, Bahasa Daerah akhirnya berhasil dimasukkan kedalam UUD 1945. Dalam pasal 32 ayat 2 dinyatakan bahwa Negara menghormati dan memelihara Bahasa Daerah sebagai kekayaan Budaya Nasional. Eksistensi bahasa didalam suatu entitas integral yang bernama budaya memang telah diakui bahkan diberikan kebebasan bagi siapa saja untuk mengembangkan dan memeliharanya (ayat 1). Tetapi sayangnya, hingga saat ini tidak ada implementasi kongkret yang telah dilakukan oleh Pemerintah untuk memlihara apalagi untuk mengembangkan bahasa-bahasa daerah yang berjumlah 500 lebih tersebar di seluruh penjuru Nusantara. Padahal, eksistensi bahasa daerah sangat berperan dalam menjaga keberlangsungan pluralitas di Indonesia.

\section{UU No. 24 tahun 2009}

Kebijakan bahasa ini memang tidak semata-mata mengatur tentang Bahasa Indonesia meskipun demikian ini adalah satu-satunya undang-undang yang mengatur pemakaian Bahasa Indonesia setelah 81 tahun lalu Bahasa Indonesia diikrarkan sebagai bahasa persatuan.

UU no 24 tahun 2009 ini merupakan salah satu upaya Perencanaan Status Bahasa Indonesia. Ada 7 jenis status yang harus diperankan oleh Bahasa Indonesia, yaitu sebagai Bahasa Nasional (pasal 25), Bahasa Negara (pasal 26-28 dan 32), Bahasa resmi (30-34), Bahasa Pendidikan (29), Bahasa Ilmu pengetahuan (35), Bahasa bisnis dan perdagangan (37) dan Bahasa Media Massa (39). Ketujuh peranan bahasa indonesia tersebut memiliki andil dalam mengukuhkan integritas bangsa yang dibangun diatas keragaman (pluralitas) suku, bahasa, budaya, dll yang terbentang sepanjang 13 ribu pulau dari Aceh sampai Papua. Integritas bangsa merupakan keadaan bersatu atau tidak terpecah belahnya suatu bangsa. Maka, bahasa indonesia berperan seperti tali yang kuat yang harus mengikat erat kemajemukan tersebut dalam bingkai Pancasila dan Bhineka Tunggal Ika.

\section{Perpres no. 16 tahun 2010}

Perpres no. 16 tahun 2010 ini adalah salah satu implementasi UU 24/2009 yang mengatur tentang pemakaian Bahasa Indonesia dalam pidato resmi oleh Presiden dan Wakil Presiden pada forum-forum internasional baik didalam maupun diluar negeri (pasal 28). Penggunaan Bahasa Indonesia dalam pidato kenegaraan di luar negeri haruslah menjadi bukti kecintaan sekaligus kebanggan para pemimpin Indonesia 
akan bahasa nasionalnya sendiri. Keberadaan bahasa nasional ditengah bahasa bahasa asing dalam forum internasional merupakan identitas bangsa indonesia sendiri dan simbol kedaulatan dan kehormatan negara di hadapan masyarakat internasional.

Sedangkan, penggunaan Bahasa Indonesia pada pidato resmi Presiden dan wakil presiden di dalam negeri pada forum-forum internasional adalah wujud konsistensi para pejabat negara untuk tetap setia menggunakan Bahasa Indonesia dan juga cinta dan bangga terhadap bahasanya. Ini juga merupakan bentuk keteladanan para pemimpin bangsa kepada rakyatnya dalam hal ketaatan berbahasa Indonesia.

\section{Permendag no. 22 tahun 2010}

Peraturan Menteri Perdagangan no. 22 tahun 2010 ini juga merupakan implementasi dari pasal 37 UU no. 24 tahun 2009 yang mewajibkan pemakaian Bahasa Indonesia dalam penyampaian informasi tentang produk barang atau jasa produksi buatan dalam negeri maupun luar negeri yang beredar di Indonesia. Kementerian perdagangan telah menentukan jenis-jenis barang harus diberi nama dan juga memiliki buku petunjuk penggunaan (manual) dalam bahasa indonesia.

Maka, secara ringkas, implikasi dari Kebijakan Bahasa yang ada dan hubungannya dengan identitas, integritas dan pluralitas bangsa indonesia ditunjukkan melalui bagan dibawah ini.

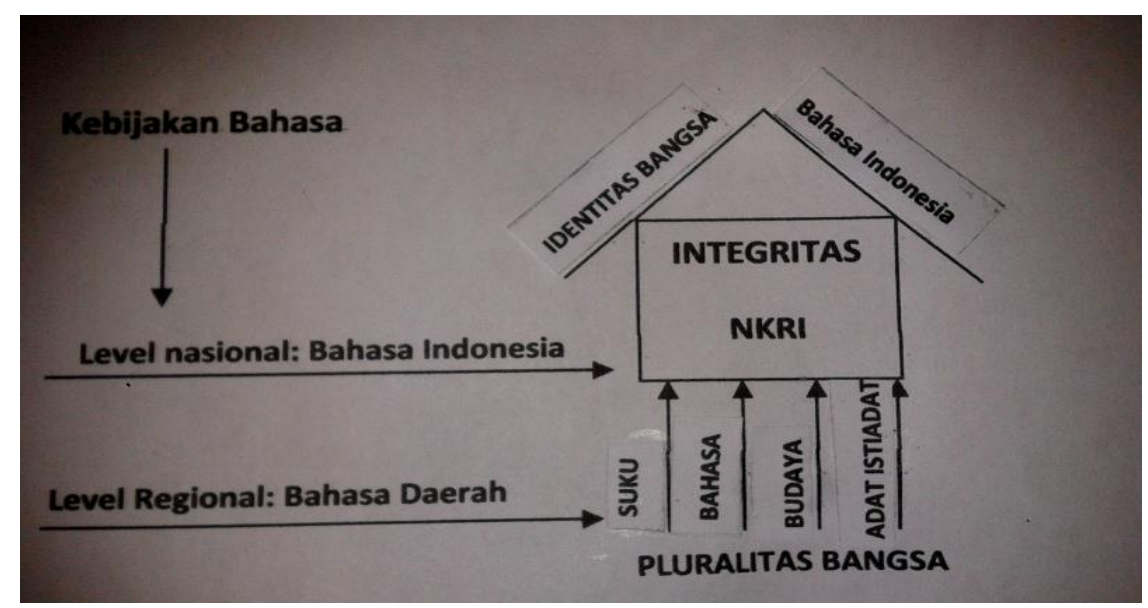

\section{KESIMPULAN DAN SARAN}

1. Banyak masalah yang mendorong pentingnya implementasi kebijakan bahasa dalam kehidupan bermasyarakat dan berbangsa antara lain masalah non-kebahasaan (pengaruh globalisasi dan ancaman disintegrasi bangsa) terlebih lagi masalah kebahasaan yang terjadi pada 2 ranah, yaitu: pada skala nasional (sikap berbahasa 
dan intervensi bahasa Inggris terhadap penggunaan bahasa Indonesia) dan pada skala regional (kepunahan dan pergeseran bahasa-bahasa lokal).

2. Ada 4 kebijakan bahasa yang sedang diterapkan di Indonesia,yakni pasal 32 dan 36 UUD 1945, UU No. 24/2009, Perpres No.10/2010, Permendag No. 22/2010.

3. Regulasi kebahasaan yang diimplentasikan akan berimplikasi terhadap penguatan Identitas, Intergritas, dan pluralitas bangsa. Implikasi-implikasi tersebut antara lain :

a. Bahasa Indonesia berfungsi sebagai identitas atau jati diri sekaligus sumber kebanggan bangsa Indonesia sebagai negara yang berdaulat.

b. Bahasa Indonesia berperan sebagai tali pengikat dan lem perekat integritas dari kemajemukan suku, bahasa dan budaya yang sangat tinggi di Indonesia dalam bingkai Bhineka Tunggal Ika.

c. Bahasa-bahasa daerah merupakan nyawa dan kunci keberlangsungan pluralitas (keragaman suku dan budaya) bangsa. Kegagalan pada pemertahanan dan pelestarian bahasa adalah kehancuran bangunan pluralitas bangsa.

d. Sudah saatnya, Pemerintah Pusat harus ikut campur menangani masalahmasalah yang muncul pada bahasa-bahasa lokal dengan cara merumuskan kebijakan bahasa yang khusus mengatur pemertahanan dan pelestarian bahasabahasa lokal yang bersifat minoritas.

\section{DAFTAR PUSTAKA}

Bamgbose, A. 1991. Language and the Nation, The Language Question in SubSaharan Africa. Edinburgh: Edinburgh University Press.

Departement Hukum dan HAM. 2009. Undang-Undang Republik Indonesia tentang Bendera, Bahasa, dan Lambang Negara serta Lagu kebangsaan. Jakarta

Garabaghi. Statur des langues et langues d'enseignement dans les \&tats membres del 'UNESCO. In Gadelli, K.E. 1999. Language Planning: Theory and Practice. UNESCO

Harrison, D.K. 2007. When Languages Die: The Extinction of the World's Languages and The Erosion of Human Knowledge. Oxford University Press.

Jendra, M.I.I. 2010. Sociolinguistics, the Studies of Societies Languages. Yogyakarta: Graha Ilmu

Kaplan, R.B. and Bauldauf, R.B.,Jr. 1997. Language Planning from Practice to Theory. Multilingual Matters. 
Kementerian Perdagangan Republik Indonesia. 2010. Peraturan Menteri Perdagangan No. 22/2010 tentang Kewajiban Pencantuman Label pada barang. Jakarta.

MPR RI. 2012. UUD Negara Republik Indonesia Tahun 1945. Jakarta: Sekretariat Jendral MPR RI

Peraturan Presiden Repulik Indonesia No. 16 tahun 2010 tentang Penggunaan Bahasa Indonesia dalam Pidato Resmi Presiden/Wakil Presiden serta Pejabat Negara lainnya. Jakarta

Sneddon, J. 2003. The Indonesian Language: its History and Role in Modern Society. Sydney: University of New South Wales Press Ltd.

UNESCO. 2011. Atlas of the World's Languages in Danger. Paris: UNESCO 